УДК 796.83.015.134/136-055.2-053.81:159.9

DOI https://doi.org/10.26661/2663-5925-2020-1-13

\title{
ТЕХНІКО-ТАКТИЧНА ПІДГОТОВКА ЮНІОРОК У БОКСІ З УРАХУВАННЯМ ОСОБЛИВОСТЕЙ ПСИХОЛОГІЧНОГО ТИПУ
}

\author{
Воронцов А. I. \\ аспірант кафедри теорії та методики фізичної культури і спорту \\ Запорізький національний університет \\ вул. Жуковського, 66, Запоріжжя, Украӥна \\ orcid.org/0000-0002-3269-273X \\ vai77@ukr.net
}

Ключові слова: маскулінні,
андрогінні, жіночій бокс,
тренування дівчат,
тренування юніорок.
У статті розглянуто вплив психологічного типу на навчання та вдосконалення техніко-тактичної підготовки в юніорок у боксі та пріоритетні напрями у тренуванні цієї вікової групи жіночого боксу.

Meта - визначити особливості психологічного типу юніорок та їхній вплив на техніко-тактичну підготовку в боксі. Матеріал $i$ методи: у дослідженні взяли участь члени збірної команди України з боксу серед юніорок віком 14-16 років. Усього було опитано 22 юніорки, серед яких було 7 представниць віком 14 років, 14 представниць віком 15 років та 1 представниця віком 16 років. Використані методи дослідження: методика С. Бем «Маскулінність-фемінність»; методиказ визначення маскулінності Фрайбурзького особистісного опитувальника (FPI); анкетування за допомогою розроблених власних анкет; аналіз та узагальнення літературних джерел; аналіз витягів із протоколів змагань та перегляд відео півфінальних, фінальних двобоїв двох чемпіонатів України протягом 2019 року серед юніорок на початку і наприкінці року; метод математичної статистики. Результати: було визначено, що всі юніорки $(\mathrm{n}=22)$ 3 показниками індексу (IS) у діапазоні від $-0,6966( \pm 0,05)$ до 0,2322 $( \pm 0,05)$ належать до андрогінного типу згідно із класифікацією С. Бем. Визначення ознак маскулінності за допомогою тесту Фрайбурзького особистісного опитувальника показали кількість набраних балів від 3 до $9( \pm 2)$ із 14 можливих. Опитування за власними анкетами допомогло визначити пріоритети у тренуванні юніорок, а також встановити певний зв'язок 3 особистим та командним психофізичним кондиційним станом, який буде сприяти більш продуктивному тренувальному процесу юніорок у боксі. Виявлено, що 50\% респонденток віддають перевагу ігровим тренуванням, найменший пріоритет у тренуванні мають бігові вправи та тривала розминка. Спростована думка деяких учених про боязнь представниць жіночої статі отримати травму обличчя, що ніби змушує вести двобій переважно на дальній дистанції. За результатами опитування визначено, що дівчата (15 респонденток) не бояться отримати таку травму, а за певної мотивації під час двобою кількість зростає до 17 осіб. Доповнено дані провідних науковців щодо домінування андрогенного типу жіночої статі в цих вікових групах в єдиноборствах. Висновки. Установлено зв'язок психологічного типу юніорок із вибором тренувальної моделі та проявом у тактичній підготовці. Для вдосконалення тренувального процесу потрібно визначити більше індивідуальних особливостей психологічного типу юніорок, що також допоможе у прогнозуванні змагальної діяльності. 


\title{
TECHNICAL-TACTICAL PREPARATION OF JUNIORS IN BOXING TAKING INTO ACCOUNT PECULIARITIES OF PSYCHOLOGICAL TYPE
}

\author{
Vorontsov A. I. \\ Postgraduate Student at the Department of Theory and Methods of Physical Culture and Sports \\ Zaporizhzhia National University \\ Zhukovsky str., 66, Zaporizhzhia, Ukraine \\ orcid.org/0000-0002-3269-273X \\ vai77@ukr.net
}

Key words: masculinity, androgyny, women's boxing, girls training, training of juniors.
The article considers the influence of psychological type on training and improvement of training in juniors in boxing, priority areas in training. Purpose: To determine the peculiarities of the psychological type of juniors and their impact on the technical-tactical training in boxing. Material and Methods: The study involved members of the Ukrainian boxing team of juniors aged 14-16. A total of 22 juniors were interviewed: of which there were 7 female representatives aged 14, 14 ones aged 15, and 1 female representative aged 16. Methods of research used: S. Bem technique "Masculinity - femininity"; methodology for determining the masculinity of the Freiburg Personal Questionnaire (FPI); questionnaires with the help of developed personal questionnaires; analysis and synthesis of literary sources; analysis of excerpts from competition protocols and video review of semifinal, final duels of two championships of Ukraine during 2019 among juniors at the beginning of the year and at the end of the year; method of mathematical statistics. Results: It was determined that all juniors (n $=22)$ with index (IS) in the range of $-0,6966( \pm 0,05)$ to $0,2322,( \pm 0,05)$ belong to the androgynous type according to $\mathrm{S}$. Bem classification. Determining signs of masculinity using the FPI test showed the number of points scored from 3 to 9 $( \pm 2)$ out of 14 possible. In-person surveys helped prioritize coaching for juniors, and helped to establish some connection with personal and team psychophysical conditioning that would facilitate a more productive boxing training process for juniors. It was found that $50 \%$ of respondents prefer game training, running exercises have the lowest priority in training. The opinion of some scientists, about the fear of women to get facial injuries and therefore they are forced to fight mostly over long distances has been rebutted. According to the results of the survey, the girls -15 respondents, are not afraid to get such an injury, and with some motivation during the fight, the number increases to 17 people. The data of leading scientists on the dominance of the androgenic type of women in these age groups in martial arts have been supplemented. Conclusions. It was established a certain connection of psychological type of juniors with the choice of training model and its manifestation in tactical training. To improve the training process, you need to identify more individual characteristics of the psychological type of juniors, which will also help in predicting competitive activity. 
Постановка проблеми. У зв'язку зі швидким розвитком жіночого боксу, зростанням кількості змагань різних рангів на всеукраїнському та міжнародному рівнях, особливо в молодших вікових групах жіночого боксу (дівчата, юніорки), значно підвищився рівень конкуренції в цих вікових групах, що змусило тренерів звернути більше уваги на типологічні особливості дівчат-боксерів із метою найпродуктивнішого навчання, удосконалення техніко-тактичних дій у боксі. На жаль, у сучасних навчальних посібниках із жіночого боксу така проблема описана поверхово [1, с. 26 ; 2, с. 388]. Наукова і спеціальна література розрахована на висококваліфікованих жінок-боксерів [3, с. $352 ; 4$, с. 162]. Зазначене ускладнює підготовку юніорок. Визначення психологічної статі за такими ознаками, як маскулінні, андрогінні, фемінні, допоможе тренеру визначити здатність індивіда до виду спорту та диференціювати тренувальний процес дівчини-боксера.

Науковцями доведено, що для будь-якого виду спорту характерні особливості прояву психологічних якостей. Так, за дослідженнями науковців, які працюють у різних видах спорту, визначено, що спортсменки-жінки із цими ознаками психологічно і фізіологічно по-різному переносять фізичне навантаження [5, с. 44-50].

Маскулінні - більш вольові, агресивні, схильні до конкуренції, лідерства і ризику, орієнтовані на успіх, з високою самооцінкою та впевненістю у власних силах [6, с. 118]. Спортивні медики та фахівці 3 різних видів спорту і жіночого боксу визначають, що в такого типу підвищена концентрація андрогенів, яка позитивно впливає на розвиток фізичних якостей, як-от швидкість рухів, витривалість.

У психофізіологічному плані ця властивість буде проявлятися в заниженні тривожності, в адекватній реакції на стрес. Тестостерон буде сприяти поліпшенню різних видів пам'яті, просторовій орієнтації, концентрації уваги [5, с. 47].

За даними фахівців, такі типологічні особливості виявляються і в суто «жіночих» видах спорту, це доказано на прикладі спортивної аеробіки, настільного тенісу, спортивних та бальних танців [7, с. $159 ; 8$, с. $150 ; 9$, с. 80]. Фахівці це пов'язують із фізичними навантаженнями в «жіночому» спорті та зростанні спортивної кваліфікації, унаслідок чого відбувається зміна фаз МЦ, гіпертрофія м'язів, зміцнення статури [8, с. $151 ; 10$, с. 72]. Також науковці пов'язують ці особливості з вдалими виступами на змаганнях, тому що властивості, які впливають на спортивний результат у висококваліфікованих спортсменів та підлітків, не залежать від статі спортсмена [11, с. 68].

В андрогінів і фемінів такий «набір», звісно, менший, що і відображається в їхній поведінці.
Андрогінний тип жінок, присутній в умовно «чоловічих» і «жіночих» видах спорту, за різними даними, становить 34,2 та $34 \%$. За даними фахівців, універсальність такого типу в різних видах спорту полягає у прояві, у разі необхідності, фемінних та маскулінних рис характеру (ситуаційна гнучкість, здібність до центрування своїх інтересів, за необхідності), ліпшому адаптуванні до нових умов, у міжособистісних контактах у команді [6, с. 119].

До фемінного типу відносять такі властивості, як пасивність, м'якість, піклування, емоційність, чуйність, сором'язливість, готовність допомогти, поступливість, чутливість, ніжність, здатність до співчуття [6, с. 118].

За даними досліджень із різних видів спорту і єдиноборств, процентне співвідношення андрогенних властивостей у жіночої статі порівняно із представниками чоловічої статі однакового віку приблизно дорівнює 50\% [10, с. 72]. У таких же дослідженнях між жінками різного віку за різними даними прогресує зростання в бік маскулінності, але це залежить від виду спорту або окремої дисципліни та класифікації. Наприклад, учена Joanna Burdzicka-Wolowik дослідила 60 дівчат постпубертатного періоду, що займаються такими видами спорту, як бокс, дзюдо, боротьба, гімнастика, баскетбол, і визначила домінування андрогенного типу [12, с. 24]. Вітчизняний науковець К. Бугаєвський дослідив 23 дівчини постпубертатного періоду, які займаються важкою атлетикою та пауерліфтингом, зі спортивним стажем від 3 до 8 років (основна частина респонденток) та більше 8 років (4 респонденток). Дослідження показали домінування маскулінного типу за кількістю осіб - 6 спортсменок, потім андрогенного типу -4 спортсменки, фемінного типу - 1 спортсменка, але в пауерліфтингу по 5 спортсменок належали до маскулінного й андрогінного типів, 2 спортсменки - до фемінного типу. У другому дослідженні цього науковця серед 41 дівчини постпубертатного періоду, які займалися волейболом, вільною боротьбою, настільним тенісом, визначили андрогенний тип у 58,54\%, фемінний у $17,07 \%$, решта дівчат маскулінного типу [8, с. 148 ; 13 , c. 180$]$.

Мета, завдання, методи дослідження. Мета визначити особливості психологічного типу юніорок. Завдання: визначити взаємозв' язок психологічного типу та його впливу на техніко-тактичну підготовку в боксі. Матеріал: у дослідженні взяли участь члени збірної команди України з боксу серед юніорок віком 14-16 років. Усього було опитано 22 юніорки: серед яких було 7 представниць віком 14 років, 14 представниць віком 15 років та 1 представниця віком 16 років. Використані методи дослідження: методика С. Бем «Маскулінність - 
фемінність»; методика з визначення маскулінності Фрайбурзького особистісного опитувальника (далі - FPI); анкетування за допомогою розроблених власних анкет; аналіз і узагальнення літературних джерел; аналіз витягів із протоколів змагань та перегляд відео півфінальних, фінальних двобоїв двох чемпіонатів України протягом 2019 р. серед юніорок на початку і наприкінці року; метод математичної статистики.

Результати дослідження. Згідно 3 емпіричними даними фахівців у різних видах спорту, доведено, що основна частка спортсменів жіночої статі належать до андрогінного та маскулінного типів [10, с. $74 ; 14$, с. 7].

Автор провів анкетування членів юніорської збірної команди України з боксу за допомогою опитувальників С. Бем і FPI з визначення психологічного типу.

Анкетування за тестом С. Бем показало, що юніорки (n = 22) з показниками індексу (IS) у діапазоні від $-0,6966( \pm 0,05)$ до 0,2322 $( \pm 0,05)$, згідно зі шкалою, запропонованою цим психологом, від 1 до 1, належать до андрогінного типу. Відповідно до анкетування за допомогою FPI, юніорки набрали бали в діапазоні від 3 до $9( \pm 2)$ із 14 можливих, де набрана кількість балів свідчить про показники маскулінності, тобто більша кількість набраних балів означає більш виражену маскулінність.

Опитування було проведене за допомогою власних анкет, щоби визначити пріоритети у тренуванні юніорок та власну оцінку боксера тренувальної діяльності.

Відповіді на запитання показали такі результати:

1. Які види тренування у боксі більше подобається виконувати: ігрові - 11 респонденток; 3 удосконалення техніко-тактичної підготовки на боксерському мішку - 5 респонденток; 3 удосконалення техніко-тактичної підготовки в парі (відпрацювання з партнеркою ударів, серій ударів та захисту) - 6 респонденток.

2. Що найбільше не подобається у тренуванні: кросова підготовка - 2 респонденткам; бігова робота - 2 респонденткам; крос та бігова робота 1 респондентці; тривала розминка -5 респонденткам; відпрацювання - 1 респондентці; робота 3 обтяженнями - 1 респондентці.

3. 3 якої дистанції подобається або зручно вести поєдинок: дальня дистанція підходить 4 респонденткам; середня дистанція зручна для 7 респонденток; ближня дистанція подобається 2 респондентка; дальня та середня - 5 респонденткам; дальня та ближня - 1 респондентці; середня та ближня -3 респонденткам.

4. Оцінка вкладу у свій успіх на змаганнях (\%): свій - 5 респонденток; тренера - 11 респонденток; у тандемі тренера і боксера -5 респонденток. Зна- чна кількість 3 усієї команди юніорок (12 дівчат) зазначили вклад у свій успіх батьків $-55-100 \%$.

5. Страх отримати травму обличчя зазначили 7 респонденток; не бояться отримати таку травму 15 респонденток.

6. Що пріоритетне у тренуванні - не отримати травму або отримати перевагу над суперницею: не травмуватися - для 5 респонденток; превага над суперницею - для 17 респонденток.

7. Із задоволенням виконують творчі завдання під час тренування та як домашні завдання 17 респонденток; 5 не визначились.

8. Свій вклад у тренування оцінювали за 12-бальною шкалою: 20 респонденток оцінили в діапазоні від 9-12 балів; одна респондентка оцінила в 6 балів, не відповіла на запитання одна респондентка.

Проведені тестування за визначенням психологічних рис підтверджують дані провідних спеціалістів у галузі спорту про домінування маскулінного й андрогінного типів у «чоловічому» виді спорту. За результатами тестування в юніорок не було виявлено явне домінування маскулінного та фемінного типів, що свідчить про належність юніорок до андрогінного типу. Цьому типу, за визначенням фахівців, властиві така поведінка та цінності, як міжособистісні контакти в команді, спокійна реакція на зовнішній подразник, висока мотивація, самовпевненість, прояв наполегливості залежно від ситуації, схильність до більшого розвинення фізичних якостей, орієнтованість на успіх. Це підтверджують відповіді респонденток на запитання про вклад у свій успіх і здобуття переваги над суперницею, без побоювань отримати травму.

Спроба порівняти психологічний тип 3 опануванням техніко-тактичних вправ на навчально-тренувальних зборах та виступах на змаганнях на чемпіонаті України на початку і наприкінці 2019 р. показала, що всі респондентки практично підтвердили свій попередній результат. За винятком деяких респонденток, які в навчально-тренувальних зборах проявляли кращі навички. Імовірно, це пов'язано 3 іншими психологічними якостями, які треба в перспективі виявити в цих респонденток.

Відповіді на запитання, пов'язані з уподобанням видів тренування в боксі і виконання творчих завдань під час тренування та поза ним, де значна більшість юніорок вибрали таку структурну модель тренування. Що підтвердило гіпотези спеціалістів про методи тренування представниць жіночої статі в боксі, а саме тренування в ігровій формі. Завдяки такому засобу тренування проходять у сприятливій емоційній обстановці, викликають моральне й естетичне задоволення $[15$, с. 224]. Такі методи, на думку авторів, можуть бути у пріоритеті тренування юніорок у боксі. 
У результаті опитування про те, що не подобається у тренувальному процесі, визначено, що циклічна й ациклічна тренувальна робота практично рівнозначно не подобаються респонденткам. На думку автора, це свідчить про те, що необхідно більш детально вивчити психологічні риси індивіда, визначити тип нервової системи, згідно 3 отриманими даними диференціювати тренувальне навантаження. За даними спортивних психологів і фізіологів [16, с. 14], для кожного типу нервової системи характерне специфічне сприйняття фізичного навантаження, особливо у фазах менструального циклу.

Відповіді на питання, пов'язане 3 вибором дистанції, спростували твердження деяких спеціалістів про те, що боксери жіночої статі віддають перевагу дальній дистанції, неохоче йдуть на обмін ударами, тому що бояться травмувати обличчя. Автор провів аналіз відповідей на ці питання та визначив, що вести двобій на середній дистанції згодні 15 респонденток, така ж кількість не боїться зазнати травми обличчя, а за певної мотивації кількість збільшилась до 17 респонденток. Це говорить про необхідність постійного супроводження тренувального процесу мотиваційними завданнями, пов'язаними з особливостями психологічного типу.
Автор проаналізував відповіді на питання, пов'язані з оцінкою тренувального процесу, і дійшов висновку, що в юніорок досить високий емоційний рівень, який дозволяє опановувати нові завдання i, що не менш можливо, на думку спортивних психологів, які працюють із висококваліфікованими жінками-боксерами [17], вони задоволені тренувальним процесом.

Загалом, дане анкетування допомогло встановити зв'язок з особистим та командним психофізичним кондиційним станом, який буде сприяти більш продуктивному тренувальному процесу юніорок у боксі, визначити пріоритети у тренуванні цієї вікової групи.

Висновки та перспективи подальших досліджень. Встановлено певний зв'язок психологічного типу юніорок із вибором тренувальної моделі та проявом у тактичній підготовці. Для вдосконалення тренувального процесу потрібно визначити більше індивідуальних особливостей психологічного типу юніорок, що також допоможе у прогнозуванні змагальної діяльності. Подальші дослідження полягають у більш детальному індивідуальному типологічному визначенні дівчат, що займаються боксом, з метою пошуку більш раціональних шляхів засвоєння, удосконалення техніко-тактичної підготовки в боксі.

\section{ЛІТЕРАТУРА}

1. Гасанова С. Жіночий бокс : методичні рекомендації для студентів всіх спеціальностей. Київ : КНУБА, 2014. С. 26.

2. Дівочий бокс / М. Радько та ін. Чернівці : Буковинська державна медична академія, 2003. 388 с.

3. Лисицын В. Специфика технико-тактической подготовки женщин-боксеров высокого класса. Москва : Ленанд, 2014. 352 с.

4. Сактаганова T. Специальная психологическая подготовка высококвалифицированных женщин-боксеров : на примере сборной команды Казахстана : дис. ... канд. псих. наук: 13.00.04. Санкт-Петербург, 2018. 162 с.

5. Соболева Т., Соболев Д. Гиперандрогения как основа высоких результатов в женском спорте. Наука в олимпийском спорте. 2013. № 3. С. 44-50.

6. Тарасевич Е. Гендерные отличия спортсменов в различных классификационных группах видов спорта и спортивных дисциплин. Слобожсанський науково-спортивний вісник. 2016. № 2 (52). С. 117-120.

7. Ткачук М. Полозависимые характеристики высококвалифицированных спортсменок : на примере спортивной аэробики. Ученые записки университета им. П.Ф. Лесгафта. Санкт-Петербург, 2015. № 3 (121). C. 157-160. URL : https: //cyberleninka.ru/article/n/polo-zavisimye-harakteristikivysokokvalifitsirovannyh-sportsmenok-na-primere-sportivnoy-aerobiki (дата звернення: 06.03.2020).

8. Бугаевский К. Изменение показателей гендерной идентификации у девушек-спортсменок. Наука 2020. 2017. C. 144-153. URL: https://cyberleninka.ru/article/n/izuchenie-pokazateley-gendernoyidentifikatsii-u-devushek-sportcmenok (дата звернення: 07.03.2020).

9. Усольцева А. Представления о гендерной идентичности профессиональных спортсменок и девушек, профессионально не занимающихся спортом. Современные исследования социальных проблем. 2014. № 9 (41). C. 76-86. URL: http://sisp.nkras.ru (дата звернення: 10.03.2020).

10. Тарасевич О. Особливості гендерної ідентичності у спортсменів, що спеціалізуються у швидкісно-силових видах спорту. Слобожсанський науково-спортивний вісник. 2020. № 1 (75). С. 69-74.

11. Палий В. Гендерное проявления особенностей личности юных прыгунов в воду в зависимости от успешности в спорте. Известия Тульского государственного университета. Cnорт. 2019. № 3. C. 64-69. URL: https://cyberleninka.ru/article/n/gendernye-proyavleniya-osobennostey-lichnosti-yunyhprygunov-v-vodu-v-zavisimosti-ot-uspeshnosti-v-sporte (дата звернення: 07.03.2020). 
12. Burdzicka-Wolowik Joanna. Psychological gender of women taking uptypically masculine sports activity. Biomedical Human Kinetics. 2012. № 4. P. 24-28. DOI: 10.2478/v101001-012-0005-1.

13. Бугаевский К. Исследование ряда психологических показателей у спортсменок, занимающихся атлетизмом. Наука 2020. 2017. C. 176-179. URL: https://cyberleninka.ru/article/n/issledovanieryada-psihologicheskih-pokazateley-u-sportsmenok-zanimayuschihsya-atletizmom (дата звернення: 20.03.2020).

14. Burdzicka-Wolowik Joanna, Goral-Radziszewska Katrzyna. Selected personality trains of women training combat sports. Pol.j. Sport Tourism. 2014. № 21. P. 3-7. DOI: 10.2478/pjst-2014-0001.

15. Воронцов А.І. Використання ігрового методу у тренуваннях з боксу дівчат у групах базової підготовки. Сучасні проблеми фізичного виховання і спорту різних груп населення : матеріали Міжнародної науково-практичної конференції молодих учених : у 2-х т. / відп. ред. Я. Копитіна ; наук. ред. О. Томенко. Суми : СумДПУ ім. А.С. Макаренка, 2019. Т. 1. С. 221-224.

16. Шахлина Л.Я.-Г., Ковальчук Н.В. Современное представление об особенностях спортивной подготовки женщин. Спортивна медицина і фізична реабілітачія. 2018. № 1. С. 3-14.

17. Предельская Р. Гендерные различия ценностного мотивационной направленности личности боксеров в организации процесса спортивной подготовки : дис. ... канд. псих. наук: 19.00.01. Москва, 2015. $300 \mathrm{c}$.

\section{REFERENCES}

1. Gasanova S.F. (2014) Zhinochii boks. Metodychni rekomendatsii dlia studentiv vsikh spetsialnostei [Womens boxing. Methodical recommendations for students of all specialties]. Kyiv: KNUBA. (in Ukr.)

2. Redko M.M., Belykh C.I., Yusov V.L., Shaternikova A.A., Vorobyov O.O. (2003) Divochii boks [Girly boxing[. Chernivtsi : Bukovynska derzhavna medychna akademia. (in Ukr.)

3. Lisitsin V.V. (2014), Spetsifika tekhniko-takticheskoi podgotovki zhenshchin-bokserov vysokogo klassa [The specifics of the technical and tactical training of women boxers of high class]. Moskow : Lenand (in Russ.)

4. Saktaganova T.S. (2018) Sretsialnaia psikholohicheskaia podhotovka vysokokvalifitsirovanykh zhenshchin-bokserov (na primere sbornoi komandy Kazakhstana) [Special psychological training of highly qualified female boxers (for example, the national team of Kazakhstan)] (PhD Thesis), St. Petersburg : Lesgaft National State University. ( in Russ.)

5. Soboleva T., Sobolev D. (2013) Hiperandroheniia kak osnova bysokikh rezultatov v zhenskom sporte [Hyperandrogenism as the basis for high athletic perfomence in womens sports] Nauka v olimpiyskom sporte, № 3, pp. 44-50. (in Russ.)

6. Tarasevych O. (2016) Hendernye otlichiia sportsmenov v razlichnykh klasifikatsionykh vidov sporta i sportivnykh distsiplin [Gender differences of athletes in different classification groups of sport disciplines] Slobozanskyi naukovo-sportivnyi visnyk, № 2(52), pp. 117-120. DOI: 10.15391 / snsv. 2016 - 2.021 (in Russ.)

7. Tkachuk M.G., Dusenova A.A. Kokorina E.A. (2015) Polozavisimye kharakteristiki vysokokvalifitsirovanykh sportsmenok (na primere sportivnoi aerobiki) [Sex-dependent characteristics of highly qualified female athletes (by example of sports aerobics)]. Scientific notes of the University. P.F. Lesgaft (electronic journal), № 3 (121), pp. 157-160. Retrieved from: https: //cyberleninka.ru/article/n/polo-zavisimye-harakteristiki-vysokokvalifitsirovannyh-sportsmenok-na-primere-sportivnoy-aerobiki (accessed 6 March, 2020). DOI: 10.5930 / issn. 1994 - 4683. 2015. 03. 121. (in Russ.)

8. Bugaevskij K.A. (2017) Izmenenie pokazatelei gendernoi identifikatsii u devushek sportsmenok [Changes in gender identity in female athletes]. Scientific Network Edition: Science 2020 (electronic journal), pp. 144-153. Retrieved from: https://cyberleninka.ru/article/n/izuchenie-pokazateley-gendernoy-identifikatsii-u-devushek-sportcmenok (accessed 7 March, 2020). (in Russ.)

9. Usoltseva A.A. (2014) Predstavlenie o gendernoi identichnosti profesionalnykh sportsmenok i devushek, profesionalno ne zanimaiushchsia sportom [Gender identity concepts of female athletes and girls who don't do sport professionally]. Modern Research of Social Problems (electronic journal), № 9 (41), pp. 76-86. Retrieved from: http://sisp.nkras.ru (accessed 10 March, 2020). DOI: 10.12731 / 2218-7405-2014-9-6 (in Russ.)

10. Tarasevych, O., Mulik, V. (2020) Osoblyvosti gendernoi identychnosti u sportsmeniv, shcho spetsializuiutsia $\mathrm{v}$ shvidkysno-sylovykh vydakh sportu [Features of gender identity among athletes who specialize in speed-strength sports]. Slobozanskyi naukovo-sportivnyi visnyk, № 1(75), pp. 69-74. DOI: 10.15391 / snsv.2020 - 1.012 (in Ukr.)

11. Palii V.I. (2019) Gendernoe proiavleniia osobennostei lichnosti yunykh pryhunov v vodu v zavisimosti ot uspeshnosti $\mathrm{v}$ sporte [Gender manifestations of personality traits of young jumpers in water, depending on 
success in sports]. Bulletin of Tula State University. Sport (electronic journal), № 3, pp. 64-69. Retrieved from: https://cyberleninka.ru/article/n/gendernye-proyavleniya-osobennostey-lichnosti-yunyh-prygunov-v-vodu-v-zavisimosti-ot-uspeshnosti-v-sporte (accessed 7 March, 2020). (in Russ.)

12. Burdzicka-Wolowik J. (2012) Psychological gender of women taking uptypically masculine sports activity. Biomedical Human Kinetics, № 4, pp. 24-28. DOI: 10.2478 / v 101001- 012-0005-1

13. Bugaevskyi K.A. (2017) Issledovanie riada psikholohicheskikh pokazatelei u sportsmenok, zanimaiashchikhsia atletizmom [A study of some psychological parameters in athletes involved in athletics]. Scientific Network Edition: Science 2020. (electronic journal) pp. 176-182. Retrieved from: https://cyberleninka.ru/ article/n/issledovanie-ryada-psihologicheskih-pokazateley-u-sportsmenok-zanimayuschihsya-atletizmom (access March 7, 2020). (in Russ.)

14. Burdzicka-Wolowik J., Goral-Radziszewska Katrzyna. (2014) Selected personality trains of women training combat sport, Pol.j.Sport Tourism, № 21, pp. 3-7. DOI: 10.2478/pjst-2014-0001.

15. Vorontsov, A.I. (2019) Vykorystannia ihrovoho metodu $\mathrm{v}$ trenuvanniakh $\mathrm{z}$ boksu divchat $\mathrm{v}$ hrupakh bazovoi pidhotovky [Use of the game method in girls boxing training in basic training groups]. Proceedings of the Suchasni problemy fizychnogo vyhovannia i sportu riznykh grup naselennia (Ukraine, Sumy, May 23-24, 2019) (eds. Kopytna Y.M, Tomenko O.A.), Sumy: SumDPU im. A.S. Makarenko, vol. 1, pp. 222-224. (in Ukr.)

16. Shakhlina, L.Ya., Kovalchuk, N.V. (2018) Sovremennoe predstavlenie ob osobennostiakh sportivnoi podhotovki zhenchin [A contemporary view of the peculiarities of female sports preparation]. Sportyvna meditsina i fyzycna reabilitatsiia. NUFVSU, № 1 pp. 3-14. (in Russ.)

17. Predelskaia R.A. (2015) Gendernye razlichiia tsenosnoho motavatsionnoi napravlennosti lichnosti bokserov v organizatsii protsesa sportivnoi podgotovki [Gender differences in the value of the mattification orientation of the personality of boxers in the organization of the process of sports training] ( $\mathrm{PhD}$ Thesis), Moskov : GCOLIFK. (in Rus.) 